\title{
The effects of different types of management, functions, and characteristics of stands in Polish forests on the amount of coarse woody debris
}

\author{
Jan Banaś • Leszek Bujoczek · Stanisław Zięba • \\ Marek Drozd
}

Received: 24 September 2013/Revised: 7 May 2014/Accepted: 30 May 2014/Published online: 17 June 2014

(C) The Author(s) 2014. This article is published with open access at Springerlink.com

\begin{abstract}
In the modern forestry paradigm, many factors influence the amount of coarse woody debris (CWD). The present paper analyzes the effects of both local (national) programs (special functions of forests) and European programs (Natura 2000 sites), as well as the individual characteristics of forest stands. The study was conducted on 2,752 sampling plots distributed over an area of about 17,500 ha and located in lowland stands having a species composition typical of large areas in central Europe. Natura 2000 areas contained significantly more CWD $\left(8.4 \mathrm{~m}^{3} / \mathrm{ha}\right)$ than areas not covered by the program $\left(4.8 \mathrm{~m}^{3} /\right.$ ha). However, this is due to the fact that Natura 2000 sites involve well-preserved forest areas, such as nature reserves $\left(26.6 \mathrm{~m}^{3} / \mathrm{ha}\right)$. In the managed forests that have been covered by the Natura 2000 program over the past several years, the volume of CWD has not increased. Forests with ecological and social functions differed slightly in the amount of CWD. More CWD occurred in protected animal areas $\left(8.7 \mathrm{~m}^{3} / \mathrm{ha}\right)$ than in stands damaged by industry $\left(3.9 \mathrm{~m}^{3} / \mathrm{ha}\right)$. Intermediate CWD levels were found in water-protection forests and in forests located around cities and military facilities. In managed forests, the lowest CWD volume was observed in middle-aged stands. The species composition of the stand had little effect on the volume of
\end{abstract}

Communicated by J. Müller.

J. Banaś · L. Bujoczek $(\bowtie) \cdot$ S. Zięba

Department of Forest Management, Faculty of Forestry,

University of Agriculture in Krakow, A1. 29 Listopada 46,

31-425 Krakow, Poland

e-mail: leszek.bujoczek@ur.krakow.pl

M. Drozd

Department in Brzeg, Bureau for Forest Management and Geodesy, ul. Piastowska 9, 49-300 Brzeg, Poland
CWD. Only stands with a predominance of ash and alder had higher CWD levels $\left(13.5 \mathrm{~m}^{3} / \mathrm{ha}\right)$. More CWD was found in stands whose species composition did not represent the potential site quality $\left(6.4 \mathrm{~m}^{3} / \mathrm{ha}\right)$ than in habitats with the optimum species composition $\left(3.8 \mathrm{~m}^{3} / \mathrm{ha}\right)$. CWD volume should be systematically increased taking into consideration local natural conditions. Such efforts should be focused on particularly valuable regions, and especially on Natura 2000 sites, where the threshold values reported from other European forests should be reached. Leaving some trees to die naturally and retaining reasonable amounts of such trees ought to be incorporated into CWD management practice in Poland.

Keywords Coarse woody debris - Managed forest . Natura 2000 sites · Multifunctional forestry - Species composition $\cdot$ Stand age

\section{Introduction}

Due to the small overall area of unmanaged forests, it appears necessary to conserve biodiversity in managed forests. Coarse woody debris (CWD) plays an important role in the functioning of forest ecosystems, while its deficiency is considered to be one of the most important factors in the loss of forest biodiversity (Harmon et al. 1986; Siitonen 2001; Stokland et al. 2012). Previously, in forests fulfilling predominantly economic functions the role of this component of the ecosystem was underestimated and meticulous removal of dead trees was perceived as a sign of concern for forest health. Currently, multifunctional forestry recognizes the need to leave a certain number of dead trees in forests. In the face of climate changes that may lead to large-scale forest disturbances 
(Schelhaas et al. 2002), the risk of fire, pathogenic fungi, and insect outbreaks, as well as with a view to ensuring favorable environmental conditions for the development of the biodiversity of the entire forest ecosystem, the question arises as to the desirable amount and structure of CWD. The influence of deadwood on saproxylic species should be considered at different spatial scales, specifically at local and regional or landscape scales (Lachat et al. 2013). In their review of deadwood threshold data from European forests, Müller and Bütler (2010) revealed 36 critical values, but knowledge in this field is still small. The threshold ranges are $10-80 \mathrm{~m}^{3} / \mathrm{ha}$ for boreal and lowland forests and $10-150 \mathrm{~m}^{3} / \mathrm{ha}$ for mixed-montane forest, with the peak values being $20-30 \mathrm{~m}^{3} / \mathrm{ha}$ for boreal forests, $30-40 \mathrm{~m}^{3} / \mathrm{ha}$ for mixed-montane forests, and $30-50 \mathrm{~m}^{3} / \mathrm{ha}$ for lowland oak-beech forests.

Differences in the amount of CWD between unmanaged and managed forests have been repeatedly investigated and are now rather well understood (for example, Bobiec 2002; Lombardi et al. 2008). The National Forest Inventories and monitoring conducted in many countries now include CWD measurements and provide increasing knowledge about the volume, structure, and spatial distribution of deadwood in ecosystems (Travaglini et al. 2007).

The amount and structure of CWD may be affected by geographical location, stand age, developmental stage, forest type, species composition, and decomposition rate (Green and Peterken 1997; Fridman and Walheim 2000), but these differences are not always found to hold (Böhl and Brändli 2007). Another issue is detailed identification of CWD amount depending on different forms of management and environmental policies affecting CWD resources. Only knowledge of these issues will enable the creation of appropriate planning mechanisms. Some countries are introducing long-term programs aimed at increasing the volume of CWD, such as Sweden by $40 \%$ over 10 years (Anonymous 2001, quoted in Ekbom et al. 2006). Another area of research includes the different ways of increasing CWD volume in managed forests, such as artificial creation of high stumps, retention of wind-felled or naturally dying trees, manual scarification at clearcuts to avoid destruction of CWD, prolongation of the rotation period, and retention of living trees at harvest (Larsson and Danell 2001; Ranius et al. 2005). Models are being developed to predict how the quantity and quality of CWD changes during the aging of managed stands subjected to different treatment procedures (Ranius et al. 2003).

There exist many regulations directly or indirectly concerning deadwood management. The Forest Stewardship Council (FSC) requires that the amount of CWD be increased over the longer term and that the forest managing body should leave decomposing deadwood of various forms and tree species in the forest. The amount of remaining deadwood should be determined by scientific research taking into account local conditions and spatial variation. According to the Polish guidelines, fragments representing $5 \%$ of each saw timber stand should be left to die naturally and decay (Anonymous 2012). It should also be noted that different measures should be implemented for different stands to achieve a higher CWD volume (Ranius et al. 2005).

At the same time, some areas are covered by the European Natura 2000 program, which involves the preservation of certain types of natural habitats and species which are considered rare and endangered. The implementation of these objectives is often associated with the creation of suitable microhabitats, such as stumps or logs, with deadwood being one of the indicators used for assessing the conservation status of forest habitats on $\mathrm{Na}-$ tura 2000 sites (Cantarello and Newton 2008). In turn, restrictions on the amount of CWD are included in national legislation on forest health status (Forest Protection Manual 2012). This intricate system consisting of numerous requirements, specific stand characteristics, and forms of protection both under national and European Union legislation creates a relatively complex picture of the factors affecting the abundance of CWD.

The presence of CWD is often considered in terms of differences between managed and protected forests. The objective of the present paper was to investigate the effect of forest management on the amount of CWD in forests fulfilling a variety of functions (water-protection, zones around cities and military facilities, protected animal areas, areas damaged by industrial activity), also taking into consideration the various management requirements imposed on different areas (managed forests, nature reserves and Natura 2000 sites). In addition, a number of stand characteristics (age, dominant species, site quality) were taken into account. Suggestions for management were also indicated. The inventory was taken mainly in managed forests over an area representative in terms of species composition of a vast area of central Europe. The data presented include an analysis of a number of factors, and may be helpful in defining priority objectives for sustainable and multifunctional forestry, as well as in protecting species associated with deadwood.

\section{Methods}

Study site

Field studies were conducted in 2011 in south-western Poland (with the center at $50^{\circ} 31^{\prime} \mathrm{N}, 18^{\circ} 10^{\prime} \mathrm{E}$ ) on land managed by the forest division Strzelce Opolskie, State Forests-National Forest Holding (Fig. 1). The area was 


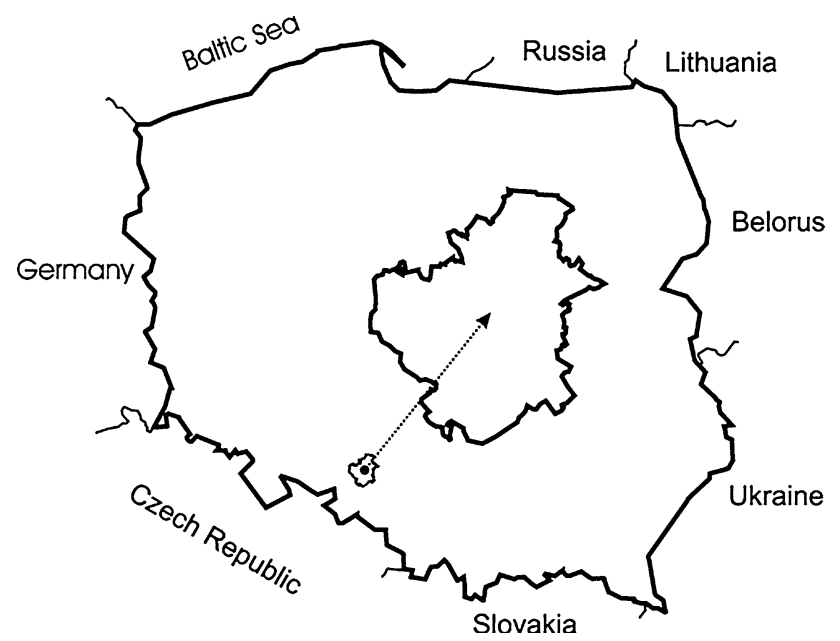

Fig. 1 Location of the study area

divided into three working sections containing 5,601 low management blocks (stands), internally uniform in terms of stand characteristics. The average stand size was 3.4 ha (0.1-34.4 ha), with a total area of about 17,500 ha. The study included stands with an age of more than 20 years, which occupied $83 \%$ of the area. Those were generally pure, one-storied, and even-aged stands. The average growing stock of the stands was about $240 \mathrm{~m}^{3} / \mathrm{ha}$. The predominant tree species in the area were Pinus sylvestris, Quercus robur, Quercus petraea, Betula pendula, Fagus sylvatica, Alnus glutinosa, Fraxinus excelsior, Picea abies, and, less frequently, Larix decidua, Acer sp., Tilia sp., Robinia pseudoacacia, Carpinus betulus, Abies alba, Populus sp., and Ulmus sp.

Types of stands

The vast majority of the area consisted of managed forests, with a small fragment covered by nature reserves. The research area was divided, according to a number of criteria, into the following subcategories (Table 1):

A. Type of management

- Forests with predominantly economic functionsmanaged forests designated primarily for timber production. Silviculture in Poland is based on forest management plans created every 10 years for individual forest divisions. The amount of yield is calculated after taking an inventory of all stands within each division. The typical rotation periods within the study area are: 80 years for Betula pendula and Alnus glutinosa, 90 for Picea abies, 100 for Pinus sylvestris, 120 for Fagus sylvatica and Fraxinus excelsior, and 140 for Quercus sp. The method of timber cutting mainly depends on the predominant species and habitat quality. Because of the predominance of Pinus sylvestris in this area, the most common method of logging is strip clearcutting with $30 \mathrm{~m}$ to $60 \mathrm{~m}$ wide strips and a maximum area of 4 ha.

Table 1 Composition of the study area: number and area of stands and plots sampled in each category

\begin{tabular}{|c|c|c|c|c|c|c|}
\hline Categories of forests & No. of stands & $\begin{array}{l}\text { No. of sampled } \\
\text { stands }\end{array}$ & $\begin{array}{l}\text { Area of } \\
\text { stands (ha) }\end{array}$ & $\begin{array}{l}\text { Area of sampled } \\
\text { stands (ha) }\end{array}$ & $\begin{array}{l}\text { No. of } \\
\text { sample plots }\end{array}$ & $\begin{array}{l}\text { Area of sample } \\
\text { plots (ha) }\end{array}$ \\
\hline Economic functions & 3,694 & 1,225 & 11,430 & 5,803 & 1,564 & 51.3 \\
\hline Ecological and social functions & 1,913 & 722 & 5,920 & 3,631 & 1,118 & 39.9 \\
\hline Around cities & 1,054 & 422 & 3,237 & 2,020 & 597 & 20.4 \\
\hline Around military facilities & 41 & 14 & 176 & 116 & 28 & 0.7 \\
\hline Protected animal areas & 76 & 27 & 242 & 156 & 60 & 2.6 \\
\hline Damaged by industry & 351 & 130 & 974 & 584 & 205 & 7.6 \\
\hline Water-protection & 391 & 129 & 1,291 & 755 & 228 & 8.6 \\
\hline Nature reserves & 33 & 26 & 211 & 203 & 70 & 3.4 \\
\hline Total study area & 5,640 & 1,973 & 17,561 & 9,637 & 2,752 & 94.6 \\
\hline \multicolumn{7}{|l|}{ Natura 2000 network } \\
\hline 9110 & 125 & 53 & 432 & 297 & 114 & 4.9 \\
\hline 9130 & 106 & 66 & 424 & 341 & 109 & 5.0 \\
\hline 9170 & 138 & 67 & 382 & 277 & 99 & 4.1 \\
\hline $91 \mathrm{~F} 0$ & 60 & 51 & 381 & 367 & 150 & 7.3 \\
\hline 91E0 & 60 & 21 & 137 & 71 & 23 & 0.7 \\
\hline Other & 18 & 4 & 38 & 18 & 5 & 0.2 \\
\hline Total Natura 2000 & 507 & 262 & 1,794 & 1,371 & 500 & 22.2 \\
\hline
\end{tabular}


- Forests with ecological (protective) and social functions-managed forests similar to forests with predominantly economic functions which, due to their location, also serve a variety of non-productive functions, both protective and social (Anonymous 1991). Depending on the function, these forests are characterized by the absence of clearcutting, prohibited use of chemicals, temporary protection areas for animal species, and an extended rotation period if logging could bother animals or if clearcutting a large area could change hydrological relations in a given area. Some of the practices in such forests follow only general guidelines and the forestry procedures applied can differ between particular cases. In the study area, the following forest types occur:

- areas around cities-these exist within the administrative boundaries of cities and up to $10 \mathrm{~km}$ from the boundaries of cities with more than fifty thousand residents; timber use is limited and clearcuts are avoid, especially near buildings and roads;

- areas around military facilities-in locations such as military training grounds;

- protected animal areas-locations where protected animals are to be found. In the study area, such zones were designated around $\mathrm{Ha}$ liaeetus albicilla and Ciconia nigra nests. These species are protected by two circular zones around their nests. The first one is species dependent and is $100 \mathrm{~m}$ in diameter for Ciconia nigra and $200 \mathrm{~m}$ in diameter for Haliaeetus albicilla, and the second one is $500 \mathrm{~m}$ in diameter for both species. Foresting activity is prohibited throughout the entire year in the former case, and during the breeding season in the latter. The zones are marked off with information boards. These protection zones may be cancelled only if the raptors permanently abandon their sites, following in-depth field assessment. Even if the nest is destroyed, the protection zone should still be maintain if the birds are still being sighted in that area, until a new nest is located. Over the time when the nest is there, the volume of deadwood can increase, especially in the former circular zone; - areas damaged by industry-these stands are permanently damaged a result of the gasses and dust emitted by industrial facilities, leading to a $25 \%$ loss of foliage and tree crown deformation. Within the study area and in its immediate vicinity there are many cement, nitrogen fertilizer, chemical, foundry, and mining facilities. In 2010, the level of air contamination with PM10 (particulate matter 10) on most measurement sites in this region exceeded the permissible limits. The concentration of benzo(a)pyrene determined in particulate matter was considerably higher than the limit $(1 \mathrm{ng} /$ $\left.\mathrm{m}^{3}\right)$;

- water-protection forests-these forests protect surface water and groundwater resources, and regulate hydrological relations in the catchment and watershed areas. There, clearcuts are limited and replaced mainly by patch cuts or only one strip of clearcut is made per decade instead of several.

- Nature reserves-in total, in the studied area there are 6 forest reserves protecting areas of special natural value, the oldest of which was established in 1958 (13.6 ha), 3 more in 1997, and the remaining ones in 2000 and 2001. In those reserves the predominant tree is beech, and in some places linden, pine, and alder. These forest stands are generally over 130-140 years old, but contain small fragments of younger stands. Some rare species have been found there, such as Cephalanthera damasonium, Corallorhiza trifida, Cephalanthera rubra, Lilium martagon, and Sorbus torminalis. In the reserves, forest management practices have not been abandoned. In some small areas, the composition of tree species has been changed to natural potential vegetation. In others, management activity has been focused on protecting rare species. In such cases, living trees can be cut and moved outside the reserves. Some deadwood is likely to be removed as well during such procedures.

\section{B. Natura 2000 network}

Some managed forests and almost the entire area of the nature reserves are included in the Natura 2000 network. In total, there are four such areas with a total forest area of 1794 ha (Table 1). The main communities are: 9110 Luzulo-Fagenion, 9130 Dentario glandulosae-Fagenion, Galio odorati-Fagenion, 9170 Galio sylvatici-Carpinetum betuli, Tilio cordatae-Carpinetum betuli, 91F0 FicarioUlmetum minoris, 91E0 Salicetum albo-fragilis, Populetum albae, and Alnenion glutinoso-incanae.

C. Forest stand species composition and potential site quality

Additional criteria for the division of stands were forest stand species composition and potential site quality in the 
management blocks (stands) (Manual of Forest Management 2003). For each management block, the optimal species composition of forest stands was determined, mainly based on soil properties and the ecological requirements of the species present in the stand. On this basis, three types may be distinguished:

- forest stand species composition represents the (local) potential site quality (potential natural vegetation, biodiversity)—such stands, fully utilizing the production capacity of the habitat rather than degrading it, occupy $44 \%$ of the area;

- forest stand species composition partly represents the (local) potential site quality-these are stands that do not take full advantage of the habitat, but have no degrading effect (they occupy $42 \%$ of the area);

- forest stand species composition does not represent the (local) potential site quality-these stands are deemed to have a degrading effect on the habitat (they occupy $14 \%$ of the area).

\section{Sampling plots}

The entire set of sampling plots comprised of stands over 20 years old, with an average height of the dominant species of at least $7 \mathrm{~m}$. The choice of stands for analysis was made using a statistical method with layers (groups of stands with the same dominant species and age class (21-30 years, $31-40, \ldots$, more than 100 years; $100-120, \ldots$ ). Layers with an area of less than 30 ha were merged with other layers containing similar species. In the first case, the number of sampling plots was calculated on the basis of formula (1), used for each working section separately. In three working sections, the total number of circular plots was 2,752, depending on the age of the stand, ranging from 50 to $500 \mathrm{~m}^{2}$. Subsequently, the total number of plots was divided according to age class. The number of plots in each age class was calculated on the basis of formulas (2) and (3). Finally, for each layer the number of sampling plots was calculated using formula (4) (Manual of Forest Management 2003).

Next, the locations of plots within the stands were randomly selected. The entire area of each working section was covered by the nodes of a grid formed by $100 \times 100 \mathrm{~m}$ squares (if necessary, $50 \times 50 \mathrm{~m}$ ). Each node was the potential center of a circular sampling plot. The random distribution of sampling plots in each layer was obtained using the Taksator software. Subsequently, the plots were divided according to the studied characteristic of the stands.

$N_{p}=400+\frac{A}{50}+1000 \times \frac{p}{A}$

where: 400 - is the minimum number of sampling plots, for which the double standard error of volume of the working section should not exceed $5 \%$; A-is the total area of all the stands being measured (ha); $p$-is the total area (ha) of stands of different species composition and age structure (not pure, one-storied and even-aged stands).

$M=N_{p}-2 L$

$n_{i}=\frac{a_{i} \cdot w_{i}}{\sum\left(a_{i} \cdot w_{i}\right)} \cdot M$

where: $L-$ number of layers; $i$ - the next age class (21-30, $31-40, \ldots) ; n-$ number of sampling plots in the $i$ age class; $a$-share of the $i$ age class in total area (\%); $w$-median of $i$ age classes $(25,35, \ldots)$

$k=\frac{b}{\sum b_{j}} \cdot n+2$

$k$-number of sampling plots in the layer; $n$-number of sampling plots in the age class which the layer belongs to; $b$ - area of the layer; $\sum b_{j}$ - total area of all the layers in the age class.

Characteristics of stands and estimation of CWD volume

Both living and dead trees were measured. In the case of living trees (with $\mathrm{DBH} \geq 7 \mathrm{~cm}$ ), height and diameter at breast height were measured, and in the case of deadwood, measurements depended on its position and type (Table 2). Stand characteristics were specified for the each management block (age, dominant species, how species composition represents potential site quality) (Manual of Forest Management 2003).

Table 2 Deadwood type definitions

\begin{tabular}{|c|c|c|}
\hline Deadwood type & Position & $\begin{array}{l}\text { Characteristics and minimum } \\
\text { thresholds for measuring } \\
\text { deadwood objects }\end{array}$ \\
\hline Entire dead trees & Standing & $\begin{array}{l}\text { Entire trees that died standing } \\
\quad(\mathrm{dbh} \geq 7 \mathrm{~cm})\end{array}$ \\
\hline Snags & Standing & $\begin{array}{l}\text { Snapped trees with a stump } \\
\text { height } \geq 1.3 \mathrm{~m}(\mathrm{dbh} \geq 7 \mathrm{~cm})\end{array}$ \\
\hline Uprooted trees & Fallen & $\begin{array}{l}\text { Wind thrown trees with exposed } \\
\text { root plates }(\mathrm{dbh} \geq 7 \mathrm{~cm})\end{array}$ \\
\hline Cutting fragments & Fallen & $\begin{array}{l}\text { Different cutting fragments of } \\
\text { trees left in the forest (diameter } \\
\text { at the larger end } \geq 10 \mathrm{~cm} \text {, } \\
\text { deadwood thinner than } 7 \mathrm{~cm} \text { in } \\
\text { diameter was not taken into } \\
\text { account) }\end{array}$ \\
\hline $\begin{array}{l}\text { Fallen dead trees, } \\
\text { trunk or branch } \\
\text { fragments }\end{array}$ & Fallen & $\begin{array}{l}\text { Fallen pieces of a trunk or large } \\
\text { branches, etc. (diameter at the } \\
\text { larger end } \geq 10 \mathrm{~cm} \text { and length } \\
\geq 10 \mathrm{~cm} \text {, deadwood thinner than } \\
7 \mathrm{~cm} \text { in diameter was not taken } \\
\text { into account) }\end{array}$ \\
\hline
\end{tabular}


To determine the total volume of standing dead trees, tree tariff tables were used for measuring height and diameter at breast height, according to the species (Czuraj 1998). The volume of snags, cut trees, fallen fragments, and uprooted trees was calculated on the basis of Huber's midsection Eq. (5) (Grochowski 1973):

$v=g_{0,5} * l$

where: $g_{0,5}$-cross-sectional area at the center of the measurement fragment, $l$ - the length or height of the fragment.

Data analysis

The area was divided into a number of small, internally uniform management blocks in terms of stand characteristics. Each stand was assigned a number of characteristics that were used for analysis, that is, the dominant tree species, stand age, management type, species composition, potential site quality, the average volume of CWD and living trees. Comparison of CWD volume was based on selected characteristics of the stands being studied. Differences between groups were determined by analysis of variance and Student's $t$ test. To describe the relationship between the average CWD volume $\left[\mathrm{m}^{3} / \mathrm{ha}\right.$ ] and the average ratio of CWD volume to the volume of living trees [\%] in particular age classes, linear, exponential, quadratic, logarithmic, and power functions were analyzed. Subsequently, the function with the highest coefficient of determination was applied to each such relationship and linearized nonlinear regression was used to check the statistical significance of the function. The species found to be dominant in the stand presented the full age range under analysis $(21-30,31-40, \ldots)$, with the last class being 100-120 years. Exceptions here were birch (not more than 90 years old) and beech-mostly over the age of 50 years. There were also several older oak stands, but they did not represent a significant share in the study area. For analysis, the medians of 10-year age classes $(25,35, \ldots, 95$ years $)$ and 110 years were adopted. Only managed forests were analyzed because nature reserve stands did not differ in terms of age (most of them were over 100 years old). Statistical analyses were conducted in STATISTICA version 9.0.

\section{Results}

Type of forest management

The average volume of CWD in the entire study area was $5.5 \mathrm{~m}^{3} /$ ha (Table 3). The share of individual types of CWD ranged from 12 to $26 \%$. The largest volume share was

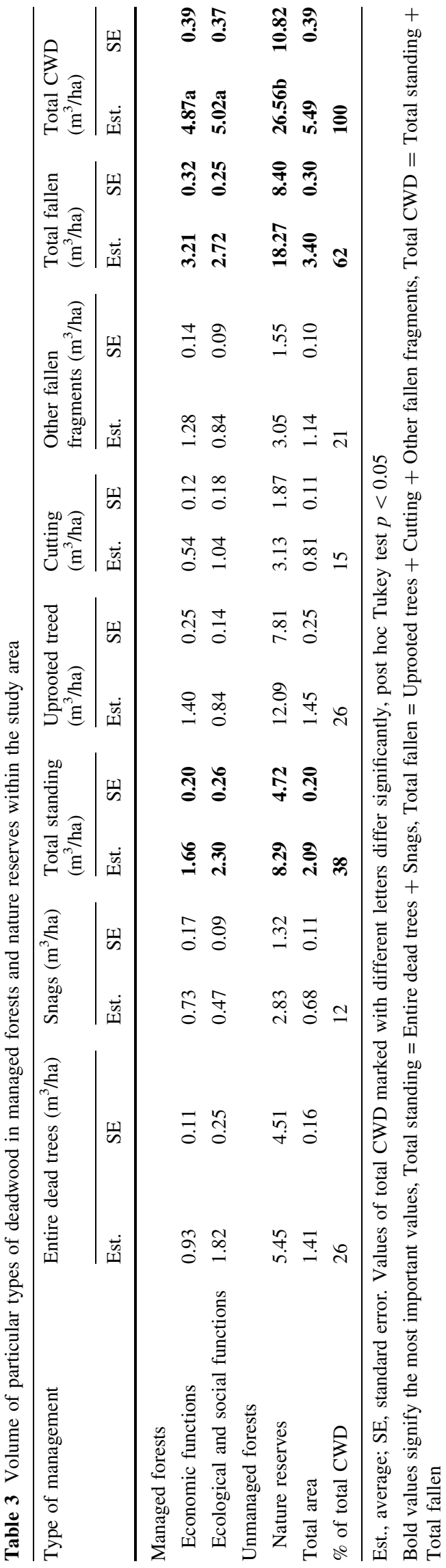


Table 4 Volume of CWD in areas covered and not covered by Natura 2000

\begin{tabular}{|c|c|c|c|c|c|c|c|c|c|c|c|c|}
\hline \multirow{3}{*}{$\begin{array}{l}\text { Natura } 2000 \\
\text { habitats }\end{array}$} & \multicolumn{6}{|c|}{ Managed forests } & \multicolumn{6}{|c|}{ Managed forests and nature reserves } \\
\hline & \multicolumn{2}{|c|}{$\begin{array}{l}\text { Total standing } \\
\left(\mathrm{m}^{3} / \mathrm{ha}\right)\end{array}$} & \multicolumn{2}{|c|}{$\begin{array}{l}\text { Total fallen } \\
\left(\mathrm{m}^{3} / \mathrm{ha}\right)\end{array}$} & \multicolumn{2}{|c|}{$\begin{array}{l}\text { Total CWD } \\
\left(\mathrm{m}^{3} / \mathrm{ha}\right)\end{array}$} & \multicolumn{2}{|c|}{$\begin{array}{l}\text { Total standing } \\
\left(\mathrm{m}^{3} / \mathrm{ha}\right)\end{array}$} & \multicolumn{2}{|c|}{$\begin{array}{l}\text { Total fallen } \\
\left(\mathrm{m}^{3} / \mathrm{ha}\right)\end{array}$} & \multicolumn{2}{|c|}{$\begin{array}{l}\text { Total CWD } \\
\left(\mathrm{m}^{3} / \mathrm{ha}\right)\end{array}$} \\
\hline & Est. & SE & Est. & SE & Est. & SE & Est. & SE & Est. & SE & Est. & SE \\
\hline No & 1.59 & 0.12 & 3.25 & 0.25 & $4.84 a$ & 0.28 & 1.59 & 0.12 & 3.25 & 0.25 & 4.84a & 0.28 \\
\hline Yes & 3.69 & 0.78 & 1.76 & 0.32 & $5.45 a$ & 0.85 & 4.34 & 0.94 & 4.07 & 1.23 & $8.41 b$ & 1.71 \\
\hline 9110 & 2.99 & 2.74 & 2.70 & 1.12 & $5.70 z$ & 3.05 & 6.23 & 3.46 & 12.25 & 5.21 & $18.48 z$ & 6.98 \\
\hline 9130 & 1.95 & 1.40 & 0.73 & 0.23 & $2.68 z$ & 1.42 & 2.33 & 1.11 & 1.40 & 0.71 & $3.73 y$ & 1.36 \\
\hline 9170 & 2.26 & 0.64 & 2.53 & 0.82 & $4.79 \mathrm{z}$ & 1.05 & 2.26 & 0.64 & 2.53 & 0.82 & $4.79 \mathrm{yz}$ & 1.05 \\
\hline $91 \mathrm{E} 0$ & 3.32 & 1.52 & 4.35 & 1.79 & $7.67 z$ & 2.40 & 3.32 & 1.52 & 4.35 & 1.79 & $7.67 \mathrm{yz}$ & 2.40 \\
\hline $91 \mathrm{~F} 0$ & 6.05 & 1.43 & 0.88 & 0.30 & $6.93 z$ & 1.46 & 6.05 & 1.43 & 0.88 & 0.30 & $6.93 \mathrm{yz}$ & 1.46 \\
\hline
\end{tabular}

Est., average; SE, standard error. Figures marked with different letters differ significantly, post hoc Tukey test $p<0.05$. Four separate analyses were conducted (in bold)

found for uprooted trees and entire dead trees, while the lowest for snags. Standing deadwood represented $38 \%$ of CWD, and fallen deadwood-62\%.

Much more CWD was found in stands protected as nature reserves $\left(26.6 \mathrm{~m}^{3} / \mathrm{ha}\right)$ than in managed forest stands (about $5 \mathrm{~m}^{3} / \mathrm{ha}$, ANOVA $F=39.6, p<0.001$ ). Both forests with predominantly economic functions and forests with ecological (protective) and social functions exhibited a similar amount of CWD. Regardless of the type of forestry management practices, fallen deadwood was the dominant form of CWD.

\section{Natura 2000: a network of protected areas}

Forests not included in the Natura 2000 network had a CWD volume of $4.8 \mathrm{~m}^{3} / \mathrm{ha}$ (Table 4$)$. Compared to Natura 2000 sites located only in managed forests $\left(5.5 \mathrm{~m}^{3} / \mathrm{ha}\right)$, the difference was not significant (Student's $t=0.82$, $p=0.41$ ). However, after including nature reserves in the analysis, a statistically significant difference was found $(t=3.56, p<0.001)$. In this case, the volume of CWD for Natura 2000 areas increased to $8.4 \mathrm{~m}^{3} / \mathrm{ha}$.

Individual habitats were also compared, but no statistical differences were identified in the case of managed forests (ANOVA $F=0.83, p=0.50$ ). However, after including nature reserves in the analysis (only habitats 9110 and 9130 were within reserves from Natura 200 sites), a significant difference was observed between these above-mentioned habitats (ANOVA $F=2.68, p<0.05$ ).

Forests with ecological (protective) and social functions

The volume of CWD in forests with different functions ranged from $3.9 \mathrm{~m}^{3} / \mathrm{ha}$ to $8.7 \mathrm{~m}^{3} /$ ha (Fig. 2). The differences were almost statistically significant (ANOVA: $F=2.35$, $p=0.05)$. Differences were found between forest stands

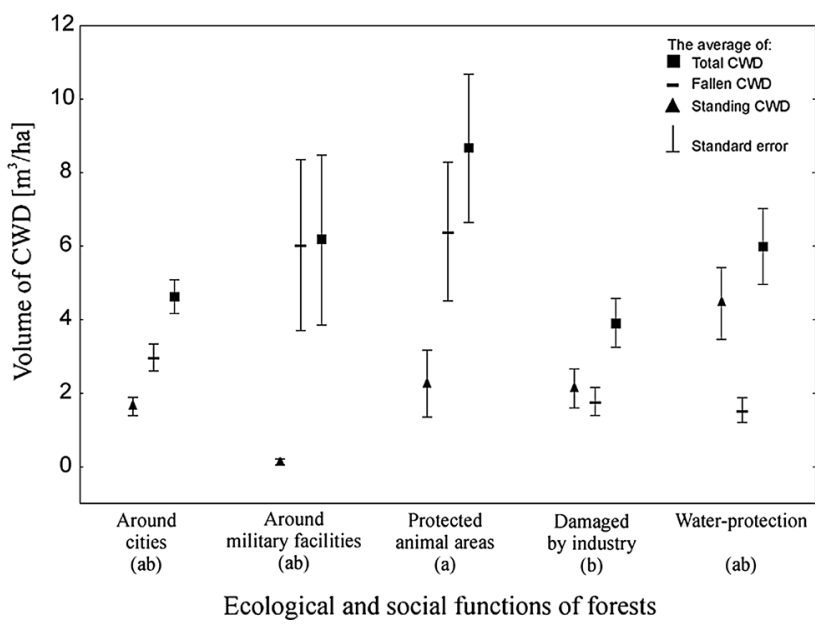

Fig. 2 CWD volume in forests with ecological (protective) and social functions. Different letters mean that total CWD differs significantly, post hoc Tukey test $p<0.05$

damaged by industry and protected animal areas (Tukey test, $p=0.048$ ). In stands damaged by industry and in water protection areas, standing CWD was predominant, whereas other areas were dominated by fallen CWD.

Dominant tree species in management blocks (stands)

Managed forests (nature reserves not included) exhibited differences between forest stands depending on the dominant species (ANOVA: $F=8.64, p<0.05$ ). These differences resulted from high CWD levels in stands dominated by ash and alder, characterized by an average volume of $13.5 \mathrm{~m}^{3} / \mathrm{ha}$, which differed significantly from other stands. In stands with a predominance of pine, beech, birch, spruce, or oak, CWD volume was about $4-6 \mathrm{~m}^{3} / \mathrm{ha}$ (Fig. 3). The share of standing CWD ranged from $22 \%$ for Betula to $61 \%$ for Quercus. 


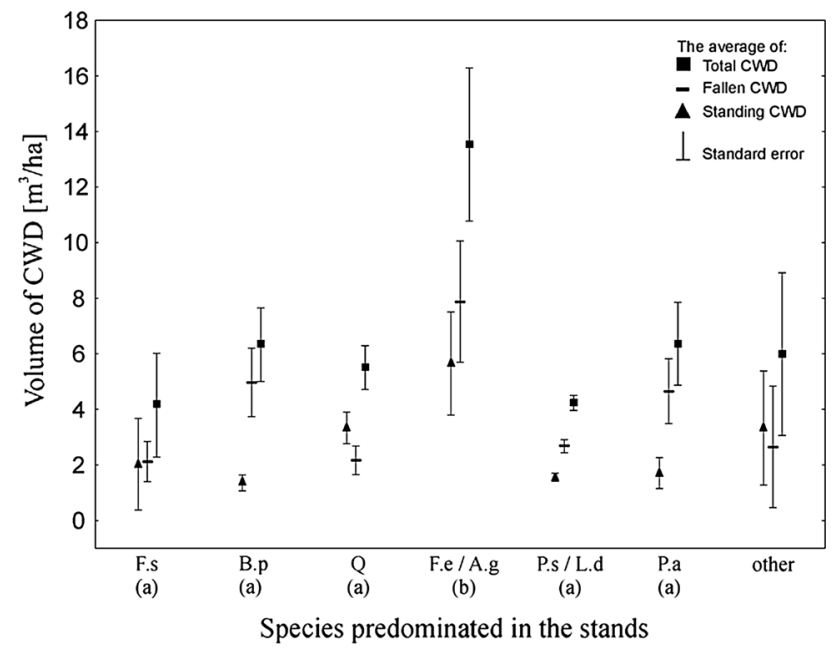

Fig. 3 CWD volume by the dominant species in the stand. Species marked by different letters differ significantly in total CWD, post-hoc Tukey test $p<0.05$. The tests do not take into account other species. (B.p - Betula pendula, F.e - Fraxinus excelsior, A.g - Alnus glutinosa, F.s - Fagus sylvatica, P.a - Picea abies, P.s - Pinus sylvestris, L.d Larix decidua, Q - Quercus sp. Other species occuring sparsely in the studied area: Carpinus betulus, Robinia pseudoacacia, Acer sp, Tilia sp, Populus tremula,Ulmus sp.)

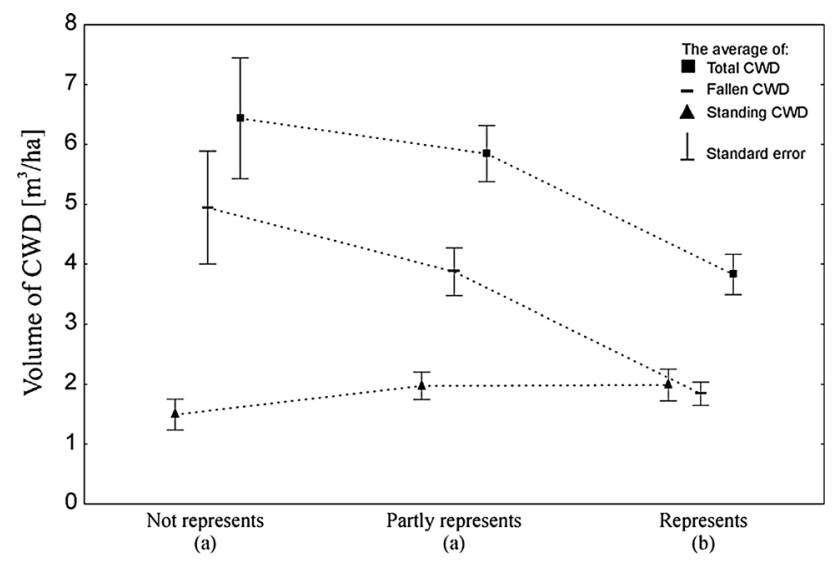

Forest stand species composition and potential site quality

Fig. 4 CWD volume by species and potential site quality. Different letters mean that total CWD differs significantly, post hoc Tukey test $p<0.05$

Forest stand species composition and potential site quality

On average, the highest levels of CWD were found in those stands (excluding nature reserves) where species composition did not represent the (local) potential site quality $\left(6.4 \mathrm{~m}^{3} / \mathrm{ha}\right)$ or represented it only to some degree $\left(5.8 \mathrm{~m}^{3} / \mathrm{ha}\right)$. There was less CWD in those stands representing the (local) potential site quality $\left(3.8 \mathrm{~m}^{3} / \mathrm{ha}\right)$. Significant differences were found between forest stands containing species representing the potential site quality and those representing it partly or not at all (ANOVA $F=7.87, p<0.001$ ). The volume of standing deadwood was similar across those stands, at about $2 \mathrm{~m}^{3} /$ ha; greater variation was found for fallen CWD (Fig. 4).

CWD as a function of stand age

The impact of stand age was analyzed excluding nature reserves, which were considerably different from the other stands and did not vary in terms of age. The volume of CWD for all species together as a function of the age of the forest stand shows a statistically significant polynomial curve of the second degree $\left(R^{2}=0.64, p<0.05\right)$. The shapes of curves were similar for all species; the minimum occurred in stands of younger and middle age classes. This relationship, however, was only statistically significant for Betula $\left(R^{2}=0.89, p<0.05\right)$ (Fig. 5).

A similar relationship, but not statistically significant, was exhibited by the ratio of CWD volume for all species to the volume of living trees $\left(R^{2}=0.57, p=0.08\right)$. However, the minimum was shifted towards older stands (60-80 years) (Fig. 6).

\section{Discussion}

\section{CWD volume}

The amount of CWD in the forest depends on the amount of deadwood supplied to the ecosystem and the rate of its decomposition. For a given species, this may vary considerably because the process is determined by many factors (Rock et al. 2008). In the study area, the average volume of the various forms of CWD was $5.5 \mathrm{~m}^{3} /$ ha, with fallen deadwood accounting for $62 \%$. Considering managed forests alone, CWD volume was close to $5.0 \mathrm{~m}^{3} / \mathrm{ha}$. These results are consistent with the currently existing volume of CWD across European forests and are very close to the average for the whole of Poland, where in 2005-2009 CWD volume was determined to be $5.7 \mathrm{~m}^{3} / \mathrm{ha}$, of which fallen deadwood accounted for nearly $60 \%$ (Anonymous 2010). Higher CWD levels have only been observed in mountain forests. There, the average CWD volume is generally greater, which is associated with the higher growing stock of stands, more difficult accessibility, and the presence of the Carpathian National Parks (Czerepko 2008). The results presented in this study are similar to those reported from Scandinavia. The average volume of deadwood on managed productive forestland in Sweden was estimated to be $6.1 \mathrm{~m}^{3} /$ ha. Of the total deadwood volume, $73 \%$ consisted of logs and $27 \%$ of snags (Fridman and Walheim 2000). Compared with Polish unmanaged forests and primeval forests, the presented data are 

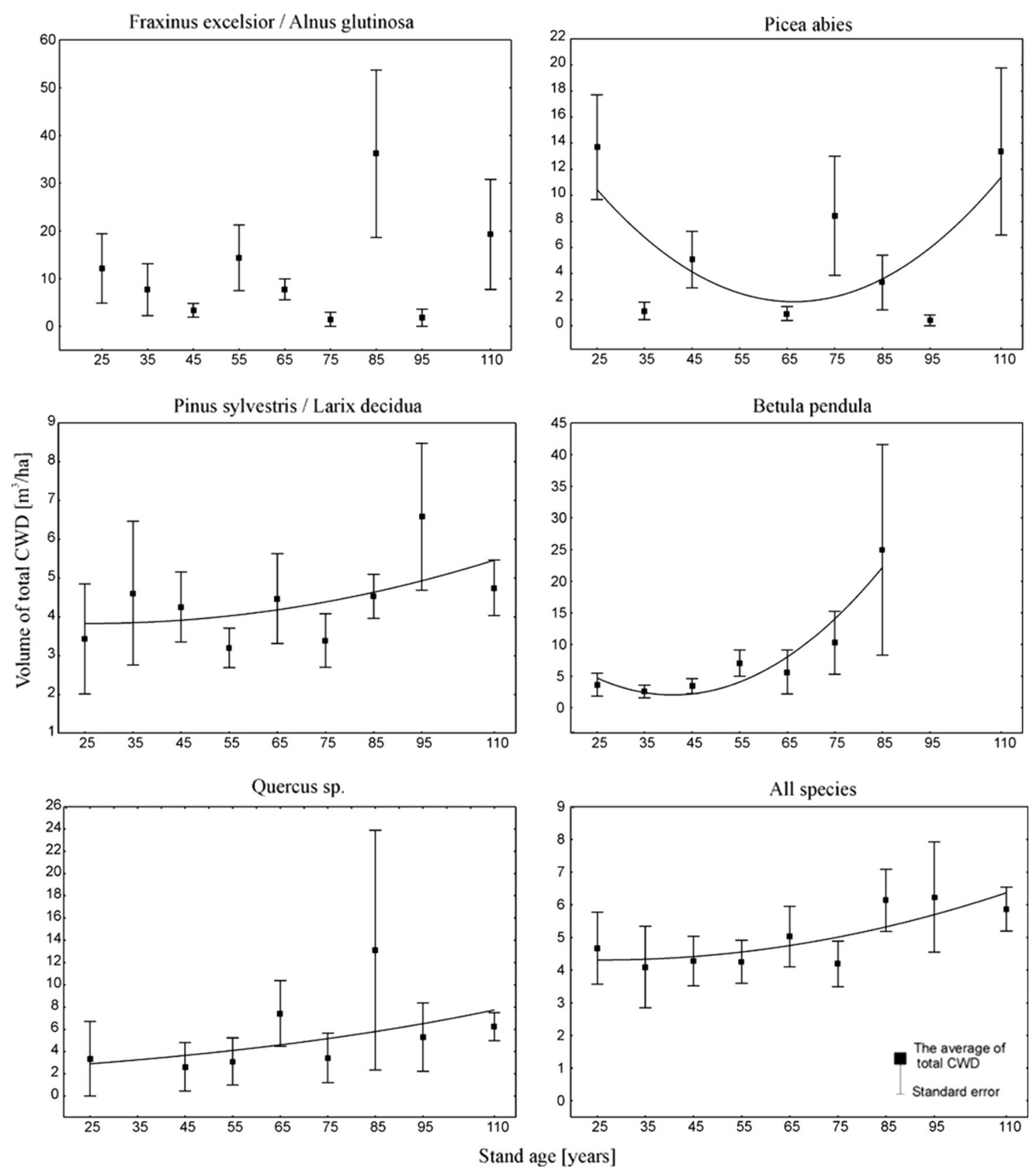

Fig. 5 The relationship between total CWD volume and stand agePinus / Larix $-R^{2}=0.30, p>0.05$; Betula $-R^{2}=0.89, p<$ 0.05 ; Quercus $-R^{2}=0.35, p>0.05$, Picea $-R^{2}=0.43, p>0.05$; all species together in the study area $R^{2}=0.64, p<0.05$. The $R^{2}$ of

much lower, as in other studies CWD volume was close to $200 \mathrm{~m}^{3} /$ ha in stands with a predominance of beech, about $150 \mathrm{~m}^{3} /$ ha for upper subalpine spruce forests, and about $100 \mathrm{~m}^{3} /$ ha for riparian forests (e.g., Holeksa 1998; Jaworski and Paluch 2001; Bobiec 2002; Zielonka 2006; Jaworski and Podlaski 2007). Nature reserves in the study area were found to have a lower CWD volume, and thus poorly supported the biodiversity of saproxylic species (Müller and Bütler 2010), which may be associated with the functions analyzed for Fraxinus / Alnus was close zero thus the curve is not shown. Quercus - exponential curve; other relationships 2nd order polynomial

fact that most of them were established in the past 15 years, and this has been shown to have a significant influence on the amount of CWD (Christensen et al. 2005). Furthermore, forest management is not entirely abandoned in nature reserves, and it is likely that some CWD is removed during different management practices.

In the stands under investigation, there appeared to be little connection between the predominant tree species and CWD volume. This may be due to the use of similar 


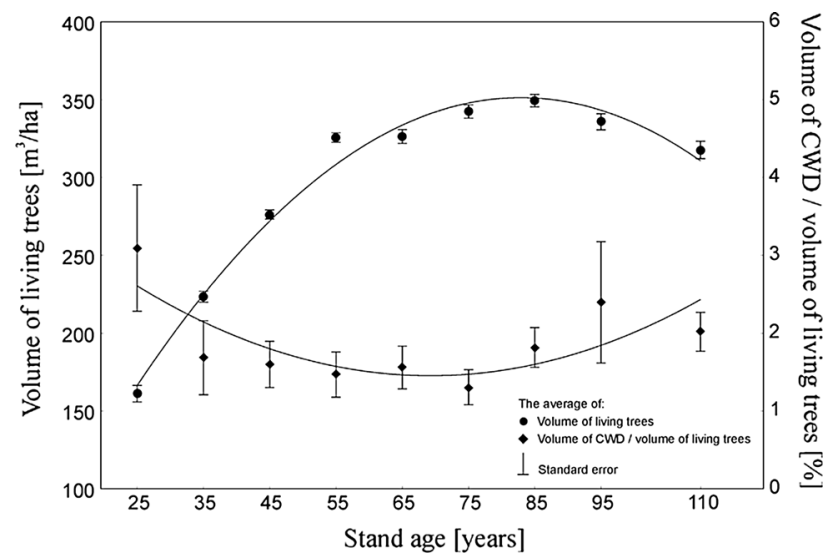

Fig. 6 Volume of living trees and the ratio of CWD volume of to the volume of living trees by stand age classVolume of living trees $-R^{2}=$ $0.98, p<0.001$; volume of CWD / volume of living trees $-R^{2}=0.57$, $p=0.08$, both curve 2 nd order polynomial

sanitary regimes regardless of species in managed forests. It is expected that such variation occurs temporarily in various stands in the presence of biotic or abiotic factors. CWD accumulation will thus be the result of the susceptibility of different species to disturbances. In the study area, only stands containing ash and alder were characterized by a higher accumulation of CWD. This may be linked to the observed dieback in ash stands, which has been found to be increasing in many Polish forests since 1992 (Kowalski 2006). The non-removal of dead trees may also be associated with wetland habitats in those stands.

It has been found that site quality influences the accumulation and overall abundance of CWD in the later stages of forest development (Sturtevant et al. 1997). However, interesting information is afforded by a comparison of stands in terms of species adaptation to habitats. Species composition carefully selected to match forest habitat conditions creates optimal conditions for the growth and development of particular tree species. Those stands where species composition corresponds to the potential site quality have a small CWD abundance, lower than the average for the entire area. This may be due to the improved health of such stands, lower susceptibility to biotic factors, and rarer deaths of trees on those sites prior to cutting age. At the same time, it may be assumed that the greater volume of CWD seen in managed forests does not result from planned actions, but rather from poor management practices in previous decades.

\section{Tree stand age}

One reason for the greater volume of CWD in nature reserves, in addition to the absence of forestry practices, is the age of those stands. Almost all nature reserve stands are more than 100 years old, while managed forests represent the full age range under study (stands older than 20 years). The lowest CWD volume in managed forests is observed in middle-aged stands (30-70 years old). Silvicultural practices play a key role in the early occurrence of deadwood (Lombardi et al. 2008). Due to logging residues, in the youngest stands CWD volume can be initially greater than in middle-aged, or even the oldest, stands. However, a rapid decrease in CWD volume was observed in the years immediately following the harvest. This results from the rapid decay rates of logging residues, which are dominated by thin wood (Moroni and Ryan 2010). In turn, in older stands CWD volume may be subject to higher increments, for the death of even a single thick tree causes a considerable accumulation of CWD. In mature stands, disturbances not only lead to an increase in the volume, but also in the structural diversity, of CWD (Sturtevant et al. 1997). In their study of a near-natural deciduous forest in central Germany, Holzwarth et al. (2013) were able to elucidate the frequently described U-form of the size (and also age) dependency of mortality as a combined product of different mechanisms related to distinct mortality modes. The reported results suggest that each mortality mode is prevalent in different stage of life-history: small trees die mostly standing or being crushed, medium-sized trees have the highest chance of survival, and very large trees experience increased rates of mortality, mainly by uprooting or snapping.

Regression curves with minima in middle-aged stands have also been reported in other studies (Ranius et al. 2003; Ekbom et al. 2006). The shape of the curves also depends on the species-in fast-growing species of lower cutting age (e.g., Betula pendula), the minimum occurred earlier than in others (e.g., Picea abies). Therefore, the average pattern for the entire study area is largely determined by the most widespread species, that was, Pinus sylvestris. Also, the rate of decomposition has an effect on the course of the curve, because rapidly decaying logging residues disappear sooner. In Boreal Newfoundland it has been found that CWD in stands $>50-60$ years is not residual, but primarily generated from regenerating tree structure (Sturtevant et al. 1997).

As a result of silvicultural practices, often based on specific guidelines, the ratio of CWD volume to the volume of living trees seems to be a better indicator in managed forest than in unmanaged forest. The ratio of dead to living wood varied greatly between the beech forest reserves studied by Christensen et al. (2005), so the amount of CWD cannot be determined by simple correlation and is often related to regional variables. In this study, the overall proportion changes with stand age and has the shape of a parabola with a minimum of $1.5 \%$ at about 70 years. 
Ecological and social functions of forests and Natura 2000 areas

The amount of deadwood in Natura 2000 areas is affected by past forest management practices (Lombardi et al. 2012). The greater amount of deadwood in the Natura 2000 areas studied is thus associated with the fact that these areas include nature reserves. In managed forests covered by the Natura 2000 program, CWD volume has changed only modestly so far. Natura 2000 is a relatively new project in this part of Europe, having been introduced in 2004. Besides, the program focuses on the maintenance of certain types of natural habitat and species without specifying how to treat microhabitats (including those formed by the different types of CWD).

Another interesting issue is the different functions fulfilled by managed stands. In Polish forests this is a statutory requirement, but nowadays in many countries managed forests are not treated as strictly timber-producing. This results from the fragmentation of forest areas and their various surroundings, often urban and industrial, fulfilling water and soil protection functions or providing protection to rare species. The average CWD volume in forests with ecological (protective) and social functions does not differ from forests with dominant economic functions. This is, amongst others, due to those very reasons why protection and socially important forests were assigned their functions. Analysis of the various forest functions reveals some differences, with the average amount of CWD being greater in stands containing protected animal areas. In turn, the lowest CWD volume is found in areas around cities and in stands damaged by industry. CWD volume is not much higher in water-protection forests, while more CWD is present in forests around military facilities. It is difficult to determine the causes of the above patterns because the various forest functions are not accompanied by guidelines for the management of CWD, which often depends on the individual opinion of forest managers in a given area. The lower CWD volume in forests damaged by industry and those around cities may be the consequence of increased sanitary regimes in those stands or the removal of deadwood from stands characterized by a greater presence of people. The opposite factors may result in a greater amount of CWD in protected animal areas, where some management practices are abandoned so as not to disturb the species that have been assigned special protection zones around nests. Also, lower activity in areas such as those around military facilities may lead to a higher average CWD volume there.

\section{Concluding remarks}

There are no rules defining the management of CWD in managed forests aside from those contained in the FSC guidelines. The application of those principles would considerably increase the amount of CWD, even in heavily managed forest landscapes. This, however, is a long-term process and it would take more than a 100 years to achieve the desired deadwood levels (Ranius and Kindvall 2004). Attempts to increase CWD in some other countries are bringing the desired effects (Böhl and Brändli 2007). A study has shown that CWD volume in forests with "new" forest clearcut stands was by about $50 \%$ higher $\left(14.2 \mathrm{~m}^{3} / \mathrm{ha}\right)$ than that in forests with "old" managed clearcuts $\left(9.3 \mathrm{~m}^{3} / \mathrm{ha}\right)$ (Ekbom et al. 2006). Still, not all methods proposed in the literature would be applicable. The adoption of a number of different measures to increase CWD in managed forests, as prescribed by certification standards today, is a valid concept, but for it to be cost efficient the focus should be on different measures in different parts of the country. Studies have also indicated that the creation of high stumps is an economical method of increasing the amount of CWD, while prolonging the rotation period is the most expensive way of increasing CWD (Ranius et al. 2005). In Poland, the creation of high stumps is limited due to the prevalent use of manual chain saws for felling. Currently, only about $5 \%$ of the timber volume harvested from state forests is felled with the help of multi-function machines (Długosiewicz and Grzebieniowski 2009). Another method, which is now under investigation, appears noteworthy. It has been found that it is always inexpensive to retain reasonable amounts of naturally dying trees, and in central and northern Sweden it is more economical to retain them than to harvest them (Ranius et al. 2005). Thus, leaving some trees to die naturally should also become part of CWD management practices in Poland.

Another issue is the spatial distribution of deadwood. CWD is often analyzed in terms of mean levels, but it would be advisable to increase its volume in some areas which are deemed important for biodiversity at the expense of other sites, to maintain a given average CWD level. Such crucial areas include Natura 2000 sites and ecological corridors. Furthermore, protected animal areas could be used to complement the above-mentioned practices, as CWD volume is already high there, but such areas account for only a small proportion of the total area under study. This is consistent with the review paper on threshold CWD values by Müller and Bütler (2010) and their conclusion that it is necessary to establish several forest stands with deadwood volume $>20-50 \mathrm{~m}^{3} / \mathrm{ha}$ in the forest landscape rather than aim at a lower mean CWD volume in all stands.

Acknowledgments We would like to extend our thanks to Janusz Szewczyk for constructive comments to the manuscript and to the National Forest Holding in Katowice for making data available to us.

Open Access This article is distributed under the terms of the Creative Commons Attribution License which permits any use, 
distribution, and reproduction in any medium, provided the original author(s) and the source are credited.

\section{References}

Anonymous (1991) Ustawa z dnia 28 września 1991 r. o lasach z późn. zm. Opracowano na podstawie: t.j. Dz. U. z 2011 r. Nr 12, poz. 59, z 2011 r. Nr 34, poz. 170

Anonymous (2010) Wielkoobszarowa inwentaryzacja stanu lasów. Wyniki I cyklu (2005-2009). Państwowe Gospodarstwo Leśne Lasy Państwowe. Forest Stary Sękocin

Anonymous (2012) Zasady, kryteria i wskaźniki dobrej gospodarki leśnej w Polsce Dokument standardów obowiązujących w certyfikacji obszarów leśnych w systemie Forest Stewardship Council w Polsce

Bobiec A (2002) Living stands and dead wood in the Bialowieza forest: suggestions for restoration management. For Ecol Manag 165(1-3):125-140. doi:10.1016/S0378-1127(01)00655-7

Böhl J, Brändli U-B (2007) Deadwood volume assessment in the third Swiss National Forest Inventory: methods and first results. Eur J For Res 126:449-457. doi:10.1007/s10342-007-0169-3

Cantarello E, Newton AC (2008) Identifying cost-effective indicators to assess the conservation status of forested habitats in Natura 2000 sites. For Ecol Manag 256:815-826. doi:10.1016/j.foreco. 2008.05.031

Christensen M, Hahn K, Mountford EP, Ódor P, Standovár T, Rozenbergar D, Diaci J, Wijdeven S, Meyer P, Winter S, Vrska T (2005) Dead wood in European beech (Fagus sylvatica) forest reserves. For Ecol Manag 210:267-282. doi:10.1016/j.foreco. 2005.02 .032

Czerepko J (2008) Stan różnorodności biologicznej lasów w Polsce na podstawie powierzchni obserwacyjnych monitoringu. Synteza wyników uzyskanych w ramach realizacji projektu BioSoil Forest Biodiversity. IBL, Sękocin Stary

Czuraj M (1998) Tablice miąższości kłód odziomkowych i drzew stojących. Wydawnictwo Świat, Warszawa

Długosiewicz L, Grzebieniowski W (2009) Porównanie wybranych technologii pozyskania drewna pod względem wydajności i kosztów. Inż Rol 8(117):7-13

Ekbom B, Schroeder LM, Larsson S (2006) Stand specific occurrence of coarse woody debris in a managed boreal forest landscape in central Sweden. For Ecol Manag 221:2-12. doi:10.1016/j.foreco. 2005.10.038

Forest Protection Manual (2012) Instrukcja ochrony lasu. Państwowe Gospodarstwo Leśne Lasy Państwowe, Warszawa

Fridman J, Walheim M (2000) Amount, structure, and dynamics of dead wood on managed forestland in Sweden. For Ecol Manag 131:23-36. doi:10.1016/S0378-1127(99)00208-X

Green P, Peterken GF (1997) Variation in the amount of dead woodlands in the woodlands of the Lower Wye Valley, UK in relation to the intensity of management. For Ecol Manag 98:229-238. doi:10.1016/S0378-1127(97)00106-0

Grochowski J (1973) Dendrometria. PWRiL, Warszawa

Harmon ME, Franklin JF, Swanson FJ, Sollins P, Gregory SV, Lattin JD, Anderson NH, Cline SP, Aumen NG, Sedell JR, Lienkaempfer GW, Cromack K, Cummins JR, Cummins KW (1986) Ecology of coarse woody debris in temperate ecosystems. Adv Ecol Res 15:133-302

Holeksa J (1998) Rozpad drzewostanu i odnowienie świerka a struktura i dynamika karpackiego boru górnoreglowego. Monogr Bot 82:1-209

Holzwarth F, Kahl A, Bauhus J, Wirth C (2013) Many ways to diepartitioning tree mortality dynamics in a near-natural mixed deciduous forest. J Ecol 101:220-230. doi:10.1111/1365-2745. 12015

Jaworski A, Paluch J (2001) Structure and dynamics of the lower mountain zone forest of primeval character in the Babia Gora Mt. National Park. J For Sci 47(2):60-74

Jaworski A, Podlaski R (2007) Structure and dynamics of selected stands of primeval character in the Pieniny National Park. Dendrobiology 58:25-42

Kowalski T (2006) Chalara fraxinea sp. nov. associated with dieback of ash (Fraxinus excelsior) in Poland. For Pathol 36:264-270. doi:10.1111/j.1439-0329.2006.00453.x

Lachat T, Bouget C, Bütler R, Müller J (2013) Deadwood: quantitative and qualitative requirements for the conservation of saproxylic biodiversity. In: Kraus D, Krumm F (eds) Integrative approaches as an opportunity for the conservation of forest biodiversity. European Forest Institute, $284 \mathrm{pp}$

Larsson S, Danell K (2001) Science and the management of boreal forest biodiversity. Scand J For Res 16(3):5-9. doi:10.1080/ 028275801300090528

Lombardi F, Lasserre B, Tognetii R, Marchetti M (2008) Deadwood in relation to stand management and forest type in Central Apennines (Molise, Italy). Ecosystem 11:882-894. doi:10.1007/ s10021-008-9167-7

Lombardi F, Klopcic M, Di Martino P, Tognetti R, Chirici G, Boncina A, Marchetti M (2012) Comparison of forest stand structure and management of silver fir-European beech forests in the Central Apennines, Italy and in the Dinaric Mountains, Slovenia. Plant Biosyst 146(1):114-123. doi:10.1080/11263504.2011.623190

Manual of Forest Management (2003) Instrukcja Urządzania Lasu. Państwowe Gospodarstwo Leśne Lasy Państwowe, Warszawa

Moroni MT, Ryan DAJ (2010) Deadwood abundance in recently harvested and old Nova Scotia hardwood forests. Forestry 83(2):219-227. doi:10.1093/forestry/cpq007

Müller J, Bütler R (2010) A review of habitat thresholds for dead wood: a baseline for management recommendations in European forests. Eur J For Res 129:981-992. doi:10.1007/s10342-0100400-5

Ranius T, Kindvall O (2004) Modelling the amount of coarse woody debris produced by the new biodiversity-oriented silvicultural practices in Sweden. Biol Conserv 119:51-59. doi:10.1016/j. biocon.2003.10.021

Ranius T, Kindvall O, Kruys N, Jonsson BG (2003) Modelling dead wood in Norway spruce stands subject to different management regimes. For Ecol Manag 182:13-29. doi:10.1016/S03781127(03)00027-6

Ranius T, Ekvall H, Jonsson M, Bostedt G (2005) Cost-efficiency of measures to increase the amount of coarse woody debris in managed Norway spruce forests. For Ecol Manag 206:119-133. doi:10.1016/j.foreco.2004.10.061

Rock J, Badeck FW, Harmon ME (2008) Estimating decomposition rate constants for European tree species from literature sources. Eur J For Res 127:301-313. doi:10.1007/s10342-008-0206-x

Schelhaas MJ, Nabuurs GJ, Sonntag M, Pussinen A (2002) Adding natural disturbances to a large-scale forest scenario model and a case study for Switzerland. For Ecol Manag 167:13-26. doi:10. 1016/S0378-1127(01)00685-5

Siitonen J (2001) Forest management, coarse woody debris and saproxylic organisms: Fennoscandian boreal forests as an example. Ecol Bull 49:11-41

Stokland JN, Siitonen J, Jonsson BG (2012) Biodiversity in dead wood. Cambridge University Press, Cambridge

Sturtevant BR, Bissonette JA, Long JN, Roberts DW (1997) Coarse woody debris as a function of age, stand structure, and disturbance in Boreal Newfoundland. Ecol Appl 7(2):702-712. doi:10.1890/1051-0761(1997)007[0702:CWDAAF]2.0.CO;2 
Travaglini D, Barbati A, Chirici G, Lombardi F, Marchetti M, Corona $\mathrm{P}$ (2007) ForestBIOTA data on deadwood monitoring in Europe. Plant Biosyst 141(2):222-230. doi:10.1080/11263500701401778
Zielonka T (2006) Quantity and decay stages of coarse woody debris in old-growth subalpine spruce forests of the western Carpathians, Poland. Can J For Res 36:2614-2622. doi:10.1139/X06-149 